\title{
INFLUENCE OF PRESS WHEELS, ROW SPACINGS AND SOWING RATES IN YIELD AND ITS COMPONENTS OF WHEAT CROP (Triticum aestivum L.) CULTIVATED BY ZERO TILLAGE METHOD IN GLYUKHAN DISTRICT
}

\author{
Nawaf J. M. Alhamadany Abdulsattar A. J. Alrijabo \\ Feld Crop Dept., College of Agriculture and Forestry, University of Mosul, \\ Iraq \\ E mail: nawaf.alhamdani.j@gmail.com
}

\begin{abstract}
A field experiment was carried out in a Moderate rainfall area (Jleokhan) in the Nineveh Governorate during the agricultural season 2018-2019 to study the effect of press wheels (use (+) and non-use (-), row spacing's $(17 \mathrm{~cm}$ and $34 \mathrm{~cm}$ ), and sowing rates $\left(80,100\right.$ and $\left.120 \mathrm{~kg} . ~ h a^{-1}\right)$ in the yield and its components of the wheat crop (Triticum aestivum L) Adana-99 cultivated with Zero Tillage (ZT) planting methods and Conventional Tillage (CT) as a control treatment.The results showed that the planting methods $(\mathrm{ZT} 17+\mathrm{P})$ and $(\mathrm{ZT} 34+\mathrm{P})$ achieved the highest significant values in the traits of plant height, the weight of 1000 grains, and grain yield. $(\mathrm{ZT} 17+\mathrm{P})$ planting method was achieved the highest significant values in the traits of tillers No. $\mathrm{m}^{-2}$, spikes No. $\mathrm{m}^{-2}$, biological yield and straw yield. The (ZT $34+\mathrm{P})$ planting method recorded the highest significant value in protein ratio trait. The sowing rate $\left(120 \mathrm{~kg}\right.$. ha $\left.{ }^{-1}\right)$ achieved the highest significant values in the traits of tillers No. $\mathrm{m}^{-2}$, spikes No. $\mathrm{m}^{-2}$, and grain yield. In grain yield trait, the interaction between the planting method $(\mathrm{ZT} 17+\mathrm{P})$ with all sowing rates and the planting method (ZT 34+P) with (120 and $100 \mathrm{~kg}$. ha ${ }^{-1}$ ) sowing rates achieved the highest significant value in grain yield, while the interaction between CT with $\left(80 \mathrm{~kg} . \mathrm{ha}^{-1}\right)$ sowing rate has the lowest significant value in grain yield.

Keywords: Conservation Agriculture, Grain yield, rain-fed planting.
\end{abstract}

Received: 26/6/2020, Accepted:14/8/2020.

\section{INTRODUCTION}

Conservative agriculture has become a major requirement in the twenty-first century with strategic crops, such as wheat (Giraldo et al., 2019). Zero-tillage systems, and sometimes minimal tillage (MT), are one of the sustainable crops Production methods that scientists around the world have sought (Farooq and Siddique.2015). In 2016, the total global land area increased to 180 million hectares, or approximately $12.5 \%$. The global increase in adoption and expansion of land under the Zero Tillage system is a result of the many benefits associated with this agricultural practice. (Kassam et al., 2019). Conservative agriculture practices have positive impact on the main soil characteristics, with reduced carbon pollution and climate protection, nutrient cycling and provision, water regulation to conservation it to the favor of crop, and reduced evaporation, and preserving soil 
biological diversity (Ghaley et al., 2018). In general, the rules for applying zero-till cultivation is due to three main principles: reducing soil irritation, improving soil cover with previous crop residues, and increasing species diversity through the agricultural cycle (Tarolli et al., 2019). In contrast, continuous tillage and removal of plant waste (Conventional Tillage) is characterized by high production costs, and it has a negative impact on soil and environmental characteristics, which leads to soil degradation, water erosion, and wind erosion, which can limit crop productivity (Santín et al., 2017). Omara et al., (2019) indicated that Zero-Tillage (ZT) can improve soil properties and crop yield. However, there are contrasting reports on its benefits compared to conventional tillage (CT). Dataset (2003-2018) from longterm continuous winter wheat (Triticum aestivum L.). Grain yield and soil nitrogen accumulation in conservative agriculture (Zero Tillage) were significantly higher than in Conventional Tillage. Bibek et al., (2019) noticed that most of the results from factors, interaction showed that the interaction between past crop residues with zero tillage following the soybean - wheat cropping system had a significantly higher effect on the wheat yield. The interaction between zero tillage with maintaining crop residues can greatly improve the physical and chemical characteristics of the soil and reduce the risk of erosion. Early emergence and rapid vegetative growth were indicated under the zero-tillage system, as the grain yield was more under zero tillage compared to the conventional tillage. (Honsdorf et al., 2019). The results of Woźniak (2020) showed that zero tillage is more effective under dry climatic conditions, while its effectiveness in rainy seasons decreases.

In Row Spacing trails, Avtar et al., (2019) were implemented in a field experiment in India, where two cultivars of wheat were planted in the 2017-2018 season to study the effect of different row spacing (at a distance of $15 \mathrm{~cm}$, and 22.5 $\mathrm{cm})$. The experiment concluded that the distance of $15 \mathrm{~cm}$ was better in the traits of plant height, accumulation of dry matter,the weight of 1000 grains, grain yield and harvest index\%.Sharma et al (2018) explained that the accumulation of the maximum dry material was recorded at a row spacing of $19.5 \mathrm{~cm}$ and the minimum accumulation of the dry material was recorded at a row spacing of $15.5 \mathrm{~cm}$. Chhokar et al., (2017) noticed that the maximum grain yield per ha was in a row spacing of $17.5 \mathrm{~cm}$ and the minimum grain yield per ha was in a row spacing of $22.5 \mathrm{~cm}$. The data of Mamta and Roopkishore (2019) revealed that wheat crop sown at higher density $\left(150 \mathrm{~kg}\right.$. ha ${ }^{-1}$ sowing rate, with a row spacing of $\left.15 \mathrm{~cm}\right)$ produced significantly more dry matter, effective tillers and finally higher grain yield as compared with (100 kg. ha ${ }^{-1}$ sowing rate and $22.5 \mathrm{~cm}$ row spacing).

In a field experiments were conducted at the Barani Agricultural Research Station- Pakistan with three varieties of bread wheat during the 2016-17 season and 2017-18 seasons using different sowing rates: $75,100,125$, and $150 \mathrm{~kg}$. ha ${ }^{-1}$. The results showed that the sowing rate of $125 \mathrm{~kg}$. ha ${ }^{-1}$ showed significantly higher values in emergence rate, plant height, and grain yield in in Fatehjang-2016 variety. (Amina et al., 2019). The results of Dongqing et al., (2019) indicated that the increase in the sowing rate significantly increased the number of tillers and the number of spikes. $\mathrm{M}^{-2}$, which led to an increase in grain yield, where the lowest grain yield was represented by the sowing rate of 75 plants. $\mathrm{M}^{-2}$, while there was no 
significant difference between the 300 plants. $\mathrm{m}^{-2}$ and 525 plants. $\mathrm{m}^{-2}$ in the trait of grain yield.

This study aims to compare between the Conventional Tillage system (CT) and the Zero Tillage system (ZT), as well as the comparison of ZT with using press wheel $(\mathrm{ZT}+\mathrm{p})$ and without using it (ZT-p), and different row spacings and sowing rates will be compared under $\mathrm{ZT}$ system too, to evaluate its effect on yield and its components of bread wheat, to find out the best multi-system for interaction between planting method, using press wheel, row spacings and sowing rates, which achieve the highest productivity of the crop, for recommending it to farmers.

\section{MATERIALS AND METHODS}

The experiment was implemented during the agricultural season 2018-2019 in farmers' fields in Glyukhan at Al-Hamdania district, which is a Moderate Rainfall Area $15 \mathrm{~km}$ southeast of the city of Mosul. Bread wheat (Triticum aestivum L.).The Adana-99 cultivar was chosen for cultivation. The experiment was implemented using a local manufactured Zero Tillage seeder (Raas Al rumh) containing press wheels parallel to the seed line opener, so that each opener followed by a press wheel which works as a compactor to the soil in the open seed line.

The study included two factors: The first factor : planting methods which included five levels: 1 - Zero Tillage planting method with $17 \mathrm{~cm}$ row spacing and use of a Press wheel (ZT 17cm+P), 2 -Zero Tillage planting method with $17 \mathrm{~cm}$ row spacing without using a Press wheel (ZT 17cm-P), 3-Zero Tillage planting method with $34 \mathrm{~cm}$ row spacing and use of a Press wheel (ZT $34 \mathrm{~cm}+\mathrm{P})$, 4-Zero Tillage planting method with $34 \mathrm{~cm}$ row spacing without using a Press wheel $(\mathrm{ZT} 17 \mathrm{~cm}-\mathrm{P})$, 5-Conventional Tillage: the field cultivated by using a disc plow before sowing (CT).

The second factor: sowing rates, which included three levels (80, 100 and 120 $\mathrm{kg} . \mathrm{ha}^{-1}$ ) for each ZT planting methods, and Conventional Tillage.

Five sowing lines were approved for each experimental unit, and reading data were collected from the middle three lines. The length of the experimental unit was $(8 \mathrm{~m})$ and the width was tow meters according to the seeders width.

Soil analysis and precipitation rates: The experiment field soil was analyzed after taking samples at a depth of $(0-30 \mathrm{~cm})$. Results of soil analysis were: Soil Texture: was Silty clay loam, OM :1.9\%, Ec (m/ds) :0.280, PH:7.2.

Monthly rainfall rates were recorded during the agricultural season, Table (1).

Table (1) Monthly precipitation, rainfall amounts (mm).

\begin{tabular}{|c|c|c|c|c|c|c|c|c|c|}
\hline \multicolumn{10}{|c|}{ Agricultural season 2018 - 2019 } \\
\hline Month & Oct & Nov & Dec & Jan & Fib & March & April & $\begin{array}{c}\text { Total } \\
(\mathrm{mm})\end{array}$ & $\begin{array}{c}\text { Total after } \\
\text { sowing }\end{array}$ \\
\hline $\mathrm{mm}$. & 44 & 117.5 & 208 & 97.5 & 36 & 231 & 296 & 830 & 660.5 \\
\hline
\end{tabular}

The Sowing date was on 11/1/2019, and the harvesting date on 6/6/2019. Fertilization and weed control: A fertilizer dose was added at the Tillering stage with a DAP fertilizer (NPK) (0-46-18), and the given amount of fertilizer was 
according to the quantity recommended by the Nineveh Agricultural Directorate at $200 \mathrm{~kg}$ ha-1,date of the addition was on 4/3/2019.

The field was sprayed with two types of herbicides, the first herbicide for thin-leaf weeds was (CLODIA-300) with (2400 ml. ha $\left.{ }^{-1}\right)$, and the second herbicide for broad-leaf weeds, which was (ACIAD-6E) with $(880 \mathrm{ml}$. ha-1) according to the manufacturer's recommended concentration of both herbicides, The spray date was on $28 / 2 / 2019$.

Studied traits: Plant height $(\mathrm{cm})$, Tillers No.m ${ }^{-2}$, Spikes No.m ${ }^{-2}$, No. of Spike grains, 1000 grains weight $(\mathrm{gm})$, Biological yield $\left(\mathrm{gm} . \mathrm{m}^{-2}\right)$, Grain yield $\left(\mathrm{gm} . \mathrm{m}^{-2}\right)$, Straw yield (gm. $\left.\mathrm{m}^{-2}\right)$, Test weight kg.Hectoliter-1, and Protein $\%$.

Statistical analysis: A factorial experiment was carried out with two factors according to the Randomized Complete Block Design (RCBD) with three replicates using split-plot design. The main plots were two planting methods and secondary plots to sowing rates. The data were analyzed by computer using the SAS program. The significant differences were used by Duncan multiple-range test (Duncan, 1955). Independent comparisons were made between treatments (row spacing $17 \mathrm{~cm}$ and $34 \mathrm{~cm}$, use and no use of press wheels, zero tillage and conventional tillage.The Duncan test was used to determine the significance, the identical letters in the tables did not differ from each other significantly according to the Duncan test with a significance level (0.05).

\section{RESULTS AND DISCUSSION \\ 1-Effect of sowing rate and planting methods on plant height $(\mathrm{cm})$.}

It is well defined from the table from the table (2) in the sowing rate factor that there were no significant differences in plant height among all sowing rates, and in the planting methods factor, the rates of planting methods ZT $17+\mathrm{P}$ and ZT $34+\mathrm{P}$ achieved the highest significant value in plant height trait. In the interaction between the two factors, the interaction ZT $34+\mathrm{P}$ with the sowing rate of $100 \mathrm{~kg}$. $\mathrm{ha}^{-1}$ achieved the highest value in plant height. In the independent comparisons (Appendix) of this trait, it was obvious the significant superiority of the row spacing $17 \mathrm{~cm}$, zero tillage, and the use of a press wheel on $34 \mathrm{~cm}$, conventional tillage and with no use respectively these results are agreed with Alrijabo et al., (2014) and Amina et al., (2019).

\section{2-Effect of sowing rate and planting methods on the No.Tillers $\mathbf{m}^{-2}$.}

It is clear from Table (3) that $120 \mathrm{~kg}$. ha-1 sowing rate exceeded significantly over the sowing rates, and in the planting methods factor, the rate of the planting method ZT $17+\mathrm{P}$ has the highest significant value in the number of this trait, and in the interaction between factors, the interaction ZT $17+\mathrm{P}$ with $120 \mathrm{~kg}$.ha-1 the sowing rate achieved the highest value in this trait. In the independent comparisons (Appendix) of this trait, it is clear the superiority of $17 \mathrm{~cm}$ on $34 \mathrm{~cm}$ and the use of a press wheel with no use while there was no significant difference between zero tillage and conventional tillage in this trait. These results are consistent with what the researcher Dongqing et al., (2019) found that the increase in the sowing rate significantly increased the number of tillers of the plant, while for the planting 
Table (2) Effect of sowing rate and planting methods on plant height (cm).

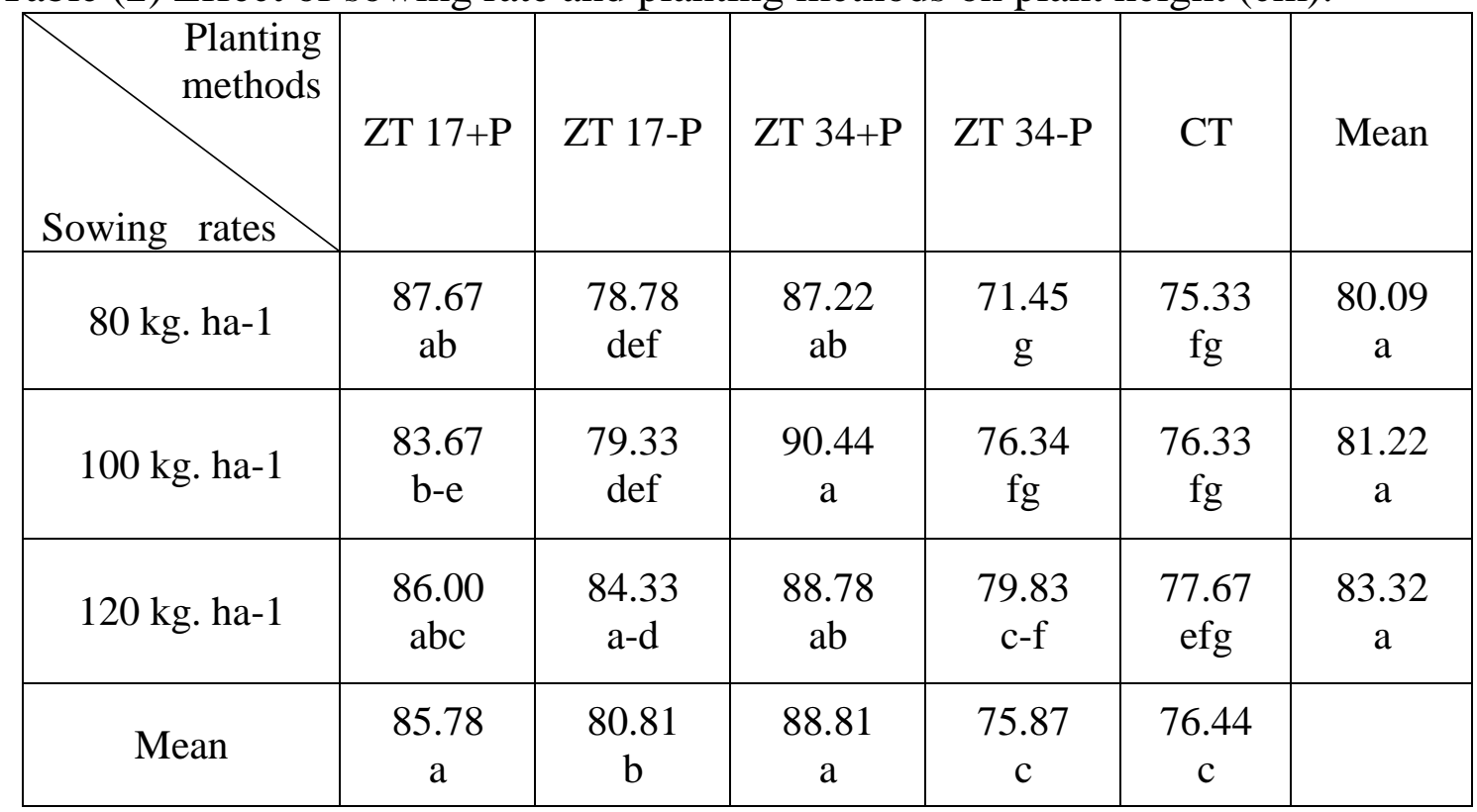

Methods, the results were consistent with what the researcher Shafaqat et al., (2016) and Latif et al., (2018) showed there is a significant increase in the number of tillers when using the zero tillage method over the conventional method. As for the row spacing, the results agreed with Al rijabo et al., (2014), and Singh et al., (2017) where narrower row spacing $17 \mathrm{~cm}$ achieved a significant increase in the number of tillers over the wide row spacing

Table (3) Effect of sowing rate and planting methods on No. of Tillers $\mathrm{m}^{-2}$.

\begin{tabular}{|c|c|c|c|c|c|c|}
\hline $\begin{array}{l}\text { Planting } \\
\text { methods } \\
\text { Sowing } \\
\text { rates }\end{array}$ & $\mathrm{ZT} 17+\mathrm{P}$ & ZT 17-P & ZT $34+\mathrm{P}$ & ZT 34-P & CT & Mean \\
\hline $80 \mathrm{~kg} \cdot \mathrm{ha}^{-1}$ & $\begin{array}{c}506.92 \\
\text { bc }\end{array}$ & $\begin{array}{c}400.20 \\
e-h\end{array}$ & $\begin{array}{c}360.72 \\
\text { gh }\end{array}$ & $\begin{array}{c}286 . .90 \\
\mathrm{i}\end{array}$ & $\begin{array}{c}355.00 \\
h\end{array}$ & $\begin{array}{c}381.95 \\
\mathrm{c}\end{array}$ \\
\hline $100 \mathrm{~kg} \cdot \mathrm{ha}^{-1}$ & $\begin{array}{c}524.71 \\
\text { bc }\end{array}$ & $\begin{array}{c}446.89 \\
\text { de }\end{array}$ & $\begin{array}{c}436.43 \\
\text { def }\end{array}$ & $\begin{array}{c}379.65 \\
\text { fgh }\end{array}$ & $\begin{array}{r}445.00 \\
\text { de }\end{array}$ & $\begin{array}{c}446.53 \\
b\end{array}$ \\
\hline $120 \mathrm{~kg} \cdot \mathrm{ha}^{-1}$ & $\begin{array}{c}589.18 \\
\mathrm{a}\end{array}$ & $\begin{array}{c}466.90 \\
\mathrm{~cd}\end{array}$ & $\begin{array}{c}534.40 \\
\mathrm{ab}\end{array}$ & $\begin{array}{c}419.73 \\
d-g\end{array}$ & $\begin{array}{c}550.00 \\
\mathrm{ab}\end{array}$ & $\begin{array}{c}512.04 \\
\mathrm{a}\end{array}$ \\
\hline Mean & $\begin{array}{c}540.27 \\
a\end{array}$ & $\begin{array}{c}438.00 \\
b\end{array}$ & $\begin{array}{c}443.85 \\
b\end{array}$ & $\begin{array}{c}362.09 \\
c\end{array}$ & $\begin{array}{c}450.00 \\
b\end{array}$ & \\
\hline
\end{tabular}

\section{3-Effect of sowing rate and planting methods on No. of spikes. $\mathrm{m}^{-2}$.}

It is clear from the table (4) in the sowing rate factor, the $120 \mathrm{~kg}$. ha ${ }^{-1}$ exceeded significantly over the other sowing rates, and in the planting methods factor, the ZT $17+\mathrm{P}$ was achieved the highest significant value in the number of spikes. In the interaction between the two factors, the interaction between ZT $17+\mathrm{P}$ and $120 \mathrm{~kg}$. ha ${ }^{-1}$ sowing rate achieved the highest value in this trait.

In the independent comparisons (Appendix), the significant superiority in this trait was in the row spacing $17 \mathrm{~cm}$ to $34 \mathrm{~cm}$, the use of a press wheel on no use it, and zero tillage on conventional tillage. These results are consistent with what 
Dongqing et al., (2019) found that the use of high sowing rates resulted in a significant increase in the number of spikes. $\mathrm{m}^{-2}$. In the method of planting, the results were consistent with what Alrijabo and Mohammed Amin (2019) found, where the use of zero tillage achieved high significant differences in the number of spikes. $\mathrm{m}^{-2}$ compared with conventional tillage, and in row spacings the results agreed with Gafari and others (2017), in that the narrow distance gave a significant difference in the number of spikes $\mathrm{m} 2$ compared to Wide distances.

Table (4) Effect of sowing rate and planting methods on No.of spikes. $\mathrm{m}^{-2}$.

\begin{tabular}{|c|c|c|c|c|c|c|}
\hline $\begin{array}{l}\text { Sowing } \\
\text { rates }\end{array}$ & ZT 17+P & ZT 17-P & ZT 34+P & ZT 34-P & CT & Mean \\
\hline $80 \mathrm{~kg} \cdot \mathrm{ha}^{-1}$ & $\begin{array}{c}480.25 \\
\text { abc }\end{array}$ & $\begin{array}{c}372.76 \\
\text { de }\end{array}$ & $\begin{array}{c}344.76 \\
\text { def }\end{array}$ & $\begin{array}{c}263.86 \\
\mathrm{fg}\end{array}$ & $\begin{array}{c}224.00 \\
\mathrm{~g}\end{array}$ & $\begin{array}{c}337.13 \\
\mathrm{c}\end{array}$ \\
\hline 100 kg.ha ${ }^{-1}$ & $\begin{array}{c}480.26 \\
\text { abc }\end{array}$ & $\begin{array}{c}383.21 \\
\text { de }\end{array}$ & $\begin{array}{c}407.90 \\
\mathrm{~cd}\end{array}$ & $\begin{array}{c}305.79 \\
\text { efg }\end{array}$ & $\begin{array}{c}244.67 \\
\mathrm{~g}\end{array}$ & $\begin{array}{c}364.37 \\
b\end{array}$ \\
\hline $120 \mathrm{~kg} \cdot \mathrm{ha}^{-1}$ & $\begin{array}{c}528.40 \\
\text { a }\end{array}$ & $\begin{array}{c}418.81 \\
\text { bcd }\end{array}$ & $\begin{array}{c}504.33 \\
\mathrm{ab}\end{array}$ & $\begin{array}{c}346.25 \\
\text { def }\end{array}$ & $\begin{array}{c}274.00 \\
\text { fg }\end{array}$ & $\begin{array}{c}414.36 \\
\mathrm{a}\end{array}$ \\
\hline Mean & $\begin{array}{c}496.30 \\
\text { a }\end{array}$ & $\begin{array}{c}391.59 \\
\text { b }\end{array}$ & $\begin{array}{c}419,00 \\
\text { b }\end{array}$ & $\begin{array}{c}305.30 \\
\mathrm{c}\end{array}$ & $\begin{array}{c}247.56 \\
d\end{array}$ & \\
\hline
\end{tabular}

\section{4-Effect of sowing rate and planting methods on No.of spike grains .}

Table (5) showed that $80 \mathrm{~kg}$. ha ${ }^{-1}$ sowing rate exceeded the highest significant value in this trait compared with $120 \mathrm{~kg}$. ha ${ }^{-1}$ sowing rate, and in the planting methods factor, ZT $34+\mathrm{P}$ achieved the highest significant value in this trait, and in the interaction between the two factors, the interaction of ZT $34+\mathrm{P}$ with $80 \mathrm{~kg}$. ha ${ }^{1}$ and $100 \mathrm{~kg}$.ha-1sowing rates gave the highest value in No.of spike grains.

In the independent comparisons (Appendix) of this trait, it is clear the significant superiority of using press wheel over its non-use and the planting method zero tillage over conventional tillage, while there was no significant difference between row spacings in this trait These results are consistent with what Amare and Mulatu (2017) found, where the lowest sowing rate gave the highest increase in the number of No. of spike grains, and the results also agreed in the method of planting with the results of Abdul Latif et al (2018) that the zero tillage gave a significant increase In the number of No. of spike grains. The only significant difference in the number of spike grains was $120 \mathrm{~kg}$. ha ${ }^{-1}$ sowing rate, which was significantly less than the sowing rate of $80 \mathrm{~kg}$.ha- 1 , and this result may be due to the superiority of No. spikes. $\mathrm{m}^{-2}$ in the $120 \mathrm{~kg}$. ha ${ }^{-1}$ sowing rate on the other sowing rates, this increase in the No.spikes. $\mathrm{m}^{-2}$ in a fixed area unit may be affected the extent of adequate minerals and water supply as a result of competition. 
Table (5) Effect of sowing rate and planting methods on No.of spike grains.

\begin{tabular}{|c|c|c|c|c|c|c|}
\hline $\begin{array}{l}\text { Sowing } \\
\text { rates }\end{array}$ & ZT 17+P & ZT 17-P & ZT 34+P & ZT 34-P & CT & Mean \\
\hline $80 \mathrm{~kg} \cdot \mathrm{ha}^{-1}$ & $\begin{array}{c}36.70 \\
\text { bc }\end{array}$ & $\begin{array}{c}31.56 \\
\text { cd }\end{array}$ & $\begin{array}{c}43.83 \\
\mathrm{a}\end{array}$ & $\begin{array}{c}28.9 \\
\text { de }\end{array}$ & $\begin{array}{c}26.00 \\
\text { de }\end{array}$ & $\begin{array}{c}33.4 \\
\mathrm{a}\end{array}$ \\
\hline $100 \mathrm{~kg} \cdot \mathrm{ha}^{-1}$ & $\begin{array}{c}37.43 \\
\text { bc }\end{array}$ & $\begin{array}{c}29.6 \\
\text { de }\end{array}$ & $\begin{array}{c}40.86 \\
\mathrm{ab}\end{array}$ & $\begin{array}{c}29.8 \\
\text { de }\end{array}$ & $\begin{array}{c}24.67 \\
\mathrm{e}\end{array}$ & $\begin{array}{c}32.5 \\
\mathrm{ab}\end{array}$ \\
\hline $120 \mathrm{~kg} \cdot \mathrm{ha}^{-1}$ & $\begin{array}{c}36.54 \\
\text { bc }\end{array}$ & $\begin{array}{c}28.27 \\
\mathrm{de}\end{array}$ & $\begin{array}{c}37.33 \\
b c\end{array}$ & $\begin{array}{c}26.27 \\
\text { de }\end{array}$ & $\begin{array}{c}25.00 \\
\mathrm{e}\end{array}$ & $\begin{array}{c}30.68 \\
\mathrm{~b}\end{array}$ \\
\hline Mean & $\begin{array}{c}36.89 \\
b\end{array}$ & $\begin{array}{c}29.81 \\
\text { c }\end{array}$ & $\begin{array}{c}40.67 \\
\mathrm{a}\end{array}$ & $\begin{array}{c}28.32 \\
\mathrm{~cd}\end{array}$ & $\begin{array}{c}25.22 \\
\mathrm{~d}\end{array}$ & \\
\hline
\end{tabular}

5-Effect of sowing rate and planting methods on the weight of 1000 grains gm . It is clear from the Table (6) that there were no significant differences in the weight of 1000 grains among all sowing rates,

Table (6) Effect of sowing rate and planting methods on the weight of 1000 grains gm .

\begin{tabular}{|c|c|c|c|c|c|c|}
\hline $\begin{array}{l}\text { Planting } \\
\text { Sowing } \\
\text { rates }\end{array}$ & $\mathrm{ZT} 17+\mathrm{P}$ & ZT 17-P & ZT 34+P & ZT 34-P & CT & Mean \\
\hline 80 kg.ha ${ }^{-1}$ & $\begin{array}{c}29.10 \\
a b\end{array}$ & $\begin{array}{c}27.10 \\
\text { abc }\end{array}$ & $\begin{array}{c}29.03 \\
\text { abc }\end{array}$ & $\begin{array}{c}28.17 \\
\text { abc }\end{array}$ & $\begin{array}{c}27.70 \\
a b c\end{array}$ & $\begin{array}{c}28.22 \\
\mathrm{a}\end{array}$ \\
\hline $100 \mathrm{~kg} \cdot \mathrm{ha}^{-1}$ & $\begin{array}{c}29.60 \\
\mathrm{a}\end{array}$ & $\begin{array}{c}27.50 \\
\text { abc }\end{array}$ & $\begin{array}{c}28.77 \\
\text { abc }\end{array}$ & $\begin{array}{c}29.23 \\
\mathrm{ab}\end{array}$ & $\begin{array}{c}26.43 \\
\text { bc }\end{array}$ & $\begin{array}{c}28.31 \\
\mathrm{a}\end{array}$ \\
\hline $120 \mathrm{~kg} \cdot \mathrm{ha}^{-1}$ & $\begin{array}{c}29.67 \\
\mathrm{a}\end{array}$ & $\begin{array}{c}27.87 \\
\text { abc }\end{array}$ & $\begin{array}{c}29.27 \\
\text { ab }\end{array}$ & $\begin{array}{c}28.33 \\
\text { abc }\end{array}$ & $\begin{array}{c}26.17 \\
\mathrm{c}\end{array}$ & $\begin{array}{c}28.26 \\
\mathrm{a}\end{array}$ \\
\hline Mean & $\begin{array}{c}29.46 \\
\mathrm{a}\end{array}$ & $\begin{array}{c}27.49 \\
\text { bc }\end{array}$ & $\begin{array}{c}29.02 \\
\mathrm{a}\end{array}$ & $\begin{array}{c}28.58 \\
a b\end{array}$ & $\begin{array}{c}26.77 \\
\mathrm{c}\end{array}$ & \\
\hline
\end{tabular}

And in the factor of planting methods, the ZT 17+P , ZT 34+P and ZT 34-P planting methods achieved highest significant value. In the interaction between the factors, there was no significant difference between all the interactions of the zero tillage planting method with all sowing rates in this trait, whereas the interaction between conventional tillage and the sowing rate of 100 and $120 \mathrm{~kg}$. Ha ${ }^{-1}$ was the lowest value in the weight of 1000 grains.

In the independent comparisons (Appendix) of this trait, the significant superiority was in the use of press wheels on non-use, and zero tillage on conventional tillage, while there was no significant difference between the row spacings $17 \mathrm{~cm}$ and $34 \mathrm{~cm}$.

\section{6-Effect of sowing rate and planting methods for biological yield gm. $\mathbf{m}^{-2}$.}

It is clear from Table (7) that there are no significant differences in the biological yield trait among all sowing rates, and in the factor of planting methods, ZT $17+\mathrm{P}$ achieved significant superiority over the rest of planting methods, and in the interaction between the two factors, the highest value in the biological yield trait 
was in the interaction between $\mathrm{ZT} 17+\mathrm{p}$ with all sowing rates. In independent comparisons (Appendix) for this trait, the significant superiority was for $17 \mathrm{~cm}$ on $34 \mathrm{~cm}$ row spacing, the use of a press wheel on Un use it, and zero tillage on conventional tillage.

Table (7) Effect of sowing rate and planting methods for biological yield gm.m ${ }^{-2}$.

\begin{tabular}{|c|c|c|c|c|c|c|}
\hline $\begin{array}{r}\text { Planting } \\
\text { methods } \\
\text { Sowing }\end{array}$ & ZT 17+P & ZT 17-P & ZT 34+P & ZT 34-P & CT & Mean \\
\hline \multirow{2}{*}{80 kg.ha-1 } & $\begin{array}{c}1142.64 \\
\text { ab }\end{array}$ & $\begin{array}{c}915.86 \\
\mathrm{c}\end{array}$ & $\begin{array}{c}834.50 \\
\mathrm{c}\end{array}$ & $\begin{array}{c}563.43 \\
\mathrm{~d}\end{array}$ & $\begin{array}{c}505.33 \\
\mathrm{~d}\end{array}$ & $\begin{array}{c}792.35 \\
\mathrm{a}\end{array}$ \\
\hline \multirow{2}{*}{$100 \mathrm{~kg}$.ha-1 } & $\begin{array}{c}1166.80 \\
\mathrm{ab}\end{array}$ & $\begin{array}{c}938.25 \\
\mathrm{c}\end{array}$ & $\begin{array}{c}922.43 \\
\mathrm{c}\end{array}$ & $\begin{array}{c}619.11 \\
\mathrm{~d}\end{array}$ & $\begin{array}{c}506.53 \\
\mathrm{~d}\end{array}$ & $\begin{array}{c}830.62 \\
\mathrm{a}\end{array}$ \\
\hline \multirow{2}{*}{$120 \mathrm{~kg}$.ha-1 } & $\begin{array}{c}1224.83 \\
\mathrm{a}\end{array}$ & $\begin{array}{c}1000.94 \\
\mathrm{bc}\end{array}$ & $\begin{array}{c}1010.91 \\
\mathrm{bc}\end{array}$ & $\begin{array}{c}629.31 \\
\mathrm{~d}\end{array}$ & $\begin{array}{c}643.07 \\
\mathrm{~d}\end{array}$ & $\begin{array}{c}901,81 \\
\mathrm{a}\end{array}$ \\
\hline \multirow{2}{*}{ Mean } & $\begin{array}{c}1178.09 \\
\mathrm{a}\end{array}$ & $\begin{array}{c}951.68 \\
\mathrm{~b}\end{array}$ & $\begin{array}{c}922.61 \\
\mathrm{~b}\end{array}$ & $\begin{array}{c}603.95 \\
\mathrm{c}\end{array}$ & $\begin{array}{c}551.64 \\
\mathrm{c}\end{array}$ & \\
\hline
\end{tabular}

In planting methods, the results of the research agreed with what Magdalena (2019) found that zero tillage planting method has achieved significant differences in the biological yield compared with conventional tillage, as well as the results of row spacing was agreed with what Abd El- Samie (2018) found that the use of a narrow row spacing of $17 \mathrm{~cm}$ resulted in a significant increase in biological weight.

\section{7-Effect of sowing rate and planting methods for grain yield $\mathbf{g m . m}$.}

It is clear from the table (8) in the sowing rate factor that $120 \mathrm{~kg} . \mathrm{ha}^{-1}$ sowing rate exceeded significantly over the other sowing rates. In the planting method factor, the mean of ZT $17+\mathrm{P}$ and ZT $34+\mathrm{P}$ achieved the highest significant value in grain yield trait, because the lowest significant value was at the conventional tillage method. In the interaction between factors, the interaction $\mathrm{ZT} 17+\mathrm{P}$ with all sowing rates achieves the highest value in grain yield, while the conventional tillage interaction with the $80 \mathrm{~kg}$. ha ${ }^{-1}$ sowing rate achieved the lowest value in the grain yield.

Table (8) Effect of sowing rate and planting methods on Grain yield gm.m ${ }^{-2}$.

\begin{tabular}{|c|c|c|c|c|c|c|}
\hline $\begin{array}{r}\text { Planting } \\
\text { Methods } \\
\text { Rates }\end{array}$ & ZT 17+P & ZT 17-P & ZT 34+P & ZT 34-P & CT & Mean \\
\hline \multirow{2}{*}{$80 \mathrm{~kg}^{2} \mathrm{ha}^{-1}$} & $\begin{array}{c}527.37 \\
\mathrm{ab}\end{array}$ & $\begin{array}{c}315.38 \\
\mathrm{de}\end{array}$ & $\begin{array}{c}440.85 \\
\mathrm{bc}\end{array}$ & $\begin{array}{c}221.64 \\
\text { efg }\end{array}$ & $\begin{array}{c}150.08 \\
\mathrm{~g}\end{array}$ & $\begin{array}{c}331.06 \\
\mathrm{~b}\end{array}$ \\
\hline \multirow{2}{*}{$100 \mathrm{~kg} \cdot \mathrm{ha}^{-1}$} & $\begin{array}{c}540.94 \\
\mathrm{ab}\end{array}$ & $\begin{array}{c}318,91 \\
\mathrm{de}\end{array}$ & $\begin{array}{c}479.38 \\
\mathrm{ab}\end{array}$ & $\begin{array}{c}271,40 \\
\text { def }\end{array}$ & $\begin{array}{c}190.65 \\
\text { fg }\end{array}$ & $\begin{array}{c}360.25 \\
\mathrm{~b}\end{array}$ \\
\hline \multirow{2}{*}{$120 \mathrm{~kg} \cdot \mathrm{ha}^{-1}$} & $\begin{array}{c}579.31 \\
\mathrm{a}\end{array}$ & $\begin{array}{c}352.26 \\
\mathrm{~cd}\end{array}$ & $\begin{array}{c}558.87 \\
\mathrm{a}\end{array}$ & $\begin{array}{c}292.26 \\
\text { def }\end{array}$ & $\begin{array}{c}281.30 \\
\text { def }\end{array}$ & $\begin{array}{c}412.80 \\
\mathrm{a}\end{array}$ \\
\hline \multirow{2}{*}{ Mean } & $\begin{array}{c}549.21 \\
\mathrm{a}\end{array}$ & $\begin{array}{c}328.85 \\
\mathrm{~b}\end{array}$ & $\begin{array}{c}493.03 \\
\mathrm{a}\end{array}$ & $\begin{array}{c}261.77 \\
\mathrm{c}\end{array}$ & $\begin{array}{c}207.34 \\
\mathrm{c}\end{array}$ & \\
\hline
\end{tabular}


In the independent comparisons (Appendix), the significant superiority was in the row spacing $17 \mathrm{~cm}$ on $34 \mathrm{~cm}$, and the use of a press wheel on Un used it, and zero tillage on conventional tillage. These results shaw that the most influential trait in achieving the highest grain yield is the trait of no. spikes. $\mathrm{m}^{-2}$ associated with the trait of No.tillers. $\mathrm{m}^{-2}$. These results are consistent with what Amina et al., (2019) found that the use of a high sowing rate gave the highest grain yield. As for planting methods, the results agreed with Honsdorf et al., (2019) that the zero tillage method achieved the highest grain yield compared to the con ventional tillage method, The results also agreed with Shafagat et al., (2016) that the narrow distance between the row spacing achieved the highest grain yield per area unit, and the results of the positive role of press wheels in increasing the grain yield agrees with the results of Asoodar and Mohajer (2014).

\section{8-Effect of sowing rate and planting methods on Straw yield gm. $\mathbf{m}^{-2}$}

From table (9), it is clear that there were no significant differences in straw yield between sowing rates. In planting methods, the mean of planting methods ZT $17+\mathrm{P}$ and ZT 17-P achieved the highest significant value in straw yield, while the lowest significant value was at the rate of conventional tillage method. Equally for the interaction between the two factors, the two interactions ZT 17+P and ZT 17-P with all sowing rates achieved the highest significant values of straw weight, while the interaction of conventional tillage with all sowing rates achieved the lowest value for straw yield. In independent comparisons (Appendix) for this trait, significant superiority achieved at $17 \mathrm{~cm}$ on $34 \mathrm{~cm}$, and zero tillage on conventional tillage, and the use of press wheels also achieved a significant advantage over not using it.

Table (9) Effect of sowing rate and planting methods on straw yield gm. $\mathrm{m}^{-2}$.

\begin{tabular}{|c|c|c|c|c|c|c|}
\hline $\begin{array}{l}\text { Sowing } \\
\text { Rates }\end{array}$ & ZT 17+P & ZT 17-P & ZT 34+P & ZT 34-P & $\mathrm{CT}$ & Mean \\
\hline 80 kg.ha ${ }^{-1}$ & $\begin{array}{c}615.27 \\
\mathrm{a}\end{array}$ & $\begin{array}{c}600.48 \\
\mathrm{a}\end{array}$ & $\begin{array}{c}395.60 \\
\text { bcd }\end{array}$ & $\begin{array}{c}341.79 \\
\mathrm{~cd}\end{array}$ & $\begin{array}{c}355.32 \\
\text { bcd }\end{array}$ & $\begin{array}{c}461.69 \\
\mathrm{a}\end{array}$ \\
\hline $100 \mathrm{~kg} \cdot \mathrm{ha}^{-1}$ & $\begin{array}{c}625.86 \\
a\end{array}$ & $\begin{array}{c}619.34 \\
\mathrm{a}\end{array}$ & $\begin{array}{c}443.05 \\
\text { bc }\end{array}$ & $\begin{array}{l}347.71 \\
\text { cd }\end{array}$ & $\begin{array}{c}315.89 \\
d\end{array}$ & $\begin{array}{c}470.37 \\
\mathrm{a}\end{array}$ \\
\hline $120 \mathrm{~kg} \cdot \mathrm{ha}^{-1}$ & $\begin{array}{c}645.52 \\
a\end{array}$ & $\begin{array}{c}648.68 \\
a\end{array}$ & $\begin{array}{c}452.03 \\
b\end{array}$ & $\begin{array}{c}337.05 \\
\mathrm{~d}\end{array}$ & $\begin{array}{c}361.71 \\
\text { bcd }\end{array}$ & $\begin{array}{c}486.02 \\
\mathrm{a}\end{array}$ \\
\hline Mean & $\begin{array}{c}628.88 \\
\mathrm{a}\end{array}$ & $\begin{array}{c}622.83 \\
\mathrm{a}\end{array}$ & $\begin{array}{c}430.23 \\
b\end{array}$ & $\begin{array}{c}342.18 \\
\text { c }\end{array}$ & $\begin{array}{c}339.16 \\
\mathrm{c}\end{array}$ & \\
\hline
\end{tabular}

These results are consistent with what Alrijabo et al., (2014), and Alrijabo and Mohammed Amin (2019) found, that the use of the zero tillage planting method resulted from the significant increase in straw yield compared to conventional tillage and the row spacings were consistent with the results of Mamta and Roopkishore ( 2019) where the row spacing $17 \mathrm{~cm}$ achieved the highest significant value in straw yield trait.

\section{9-Effect of sowing rate and planting methods on the protein $\%$.}

Table (10) showed that there are no significant differences between all sowing rate levels, in planting methods, the planting method ZT 34+P achieved the highest 
significant value in the percentage of protein $\%$. and in the interaction between the factors, the interaction of ZT $34+\mathrm{P}$ with $80 \mathrm{~kg}^{-\mathrm{ha}^{-1}}$ and $100 \mathrm{~kg}$. ha ${ }^{-1}$ sowing rates achieves the highest value in the protein ratio. In independent comparisons (Appendix) for this trait, it is clear the significant superiority of zero tillage on conventional tillage and the superiority of using press wheels on not using it, while there was no significant difference between row spacing's.

Table (10) Effect of sowing rate and planting methods on Protein \%.

\begin{tabular}{|c|c|c|c|c|c|c|}
\hline $\begin{array}{l}\text { Sowing } \\
\text { Rates }\end{array}$ & $\mathrm{ZT} 17+\mathrm{P}$ & ZT 17-P & ZT 34+P & ZT 34-P & $\mathrm{CT}$ & Mean \\
\hline $80 \mathrm{~kg} \cdot \mathrm{ha}^{-1}$ & $\begin{array}{c}11.9 \\
\mathrm{ab}\end{array}$ & $\begin{array}{c}11.7 \\
b c\end{array}$ & $\begin{array}{c}12.4 \\
\mathrm{a}\end{array}$ & $\begin{array}{c}10.8 \\
\mathrm{de}\end{array}$ & $\begin{array}{c}10.6 \\
\mathrm{e}\end{array}$ & $\begin{array}{c}11.5 \\
\mathrm{a}\end{array}$ \\
\hline $100 \mathrm{~kg} \cdot \mathrm{ha}^{-1}$ & $\begin{array}{l}11.4 \\
\text { bcd }\end{array}$ & $\begin{array}{l}11.4 \\
\text { bcd }\end{array}$ & $\begin{array}{c}12.0 \\
\mathrm{ab}\end{array}$ & $\begin{array}{l}11.2 \\
\text { cde }\end{array}$ & $\begin{array}{c}11.7 \\
\text { bc }\end{array}$ & $\begin{array}{c}11.5 \\
\mathrm{a}\end{array}$ \\
\hline $120 \mathrm{~kg} \cdot \mathrm{ha}^{-1}$ & $\begin{array}{l}11.2 \\
\text { cde }\end{array}$ & $\begin{array}{l}11.2 \\
\text { cde }\end{array}$ & $\begin{array}{c}11.7 \\
b c\end{array}$ & $\begin{array}{c}11.00 \\
\text { de }\end{array}$ & $\begin{array}{c}10.7 \\
\mathrm{e}\end{array}$ & $\begin{array}{c}11.2 \\
\mathrm{a}\end{array}$ \\
\hline Mean & $\begin{array}{c}11.5 \\
b\end{array}$ & $\begin{array}{c}11.4 \\
\mathrm{~b}\end{array}$ & $\begin{array}{c}12.0 \\
\mathrm{a}\end{array}$ & $\begin{array}{c}11.0 \\
\mathrm{c}\end{array}$ & $\begin{array}{c}11.0 \\
\mathrm{c}\end{array}$ & \\
\hline
\end{tabular}

It is evident in the trait of plant height that adding press wheels resulted in a significant increase in plant height in both rows spacing $17 \mathrm{~cm}$ and $34 \mathrm{~cm}$, and this result in this trait and other traits like,No. tillers. $\mathrm{m}^{-2}$, No.spikes. $\mathrm{m}^{-2}$ traits are due to the role of press wheels in compacting the soil above the grain line and thus achieving the highest contact between soil and grains by decreasing the air voids of the soil, the soil compacting as a result of press wheels achieved increases in water absorption by grain surface area which attached to the wet soil minutes. Thus, accelerate the germination and emergence stages, then accelerating all growth stages of the.

In the traits weight of 1000 grains, test weight, biological yield, grain yield and straw yield we notice the superiority of zero tillage in these traits comparing with conventional tillage, and this due to the efficiency of this method in rain harvesting and in the optimal distribution of grains during sowing in terms of seed depth and the distance between seed lines, which achieves the highest germination and emergence compared with conventional tillage. 


\title{
تأثير عجلات الضغط ومسافات ومعدلات البذار في الحاصل ومكوناته لمحصول الحنطة المزروع بطريقة الزراعة بدون حراثة في موقع جليوخان (Triticum aestivum L.) \\ عبدالستار اسمير جاسم الرجبو \\ نواف جاسم تحمد الحمداني \\ قسم المحاصيل الحقلية / كلية الزراعة والغابات / جامعة الموصل/ العراق \\ E mail: nawaf.alhamdani.j@gmail.com
}

\begin{abstract}
الخلاصة
نفذت تجربة حقلية في منطقة شبه مضمونة الأمطار (جليوخان) في محافظة نينوى في الموسم الزراعي

2018-2019 لدراسة تأثير عجلات الضغط Press wheel وبمستوين (استخدام P+ وعدم استخدام P-P) , ومسافتي الزراعة (17 و 34 سم) , ومعدلات البذار (80 و 100 و 120 كغم.هكتار -1) في الحاصل ومكوناته لمحصول حنطة الخبز (Triticum aestivum L) صنف أدنة-99 (Adana-99) المزروع Conventional Tillage CT. بطريقة الزراعة بدون حراثة Zعero Tillage ZT مع الزراعة التقليدية كمعاملة مقارنة ضمن توليفة خماسية تضمنت: (ZT 17cm+P) و (ZT 17cm-P) و (ZT 34cm+P) و (ZT 34cm-P) و الزراعة التقليدية (CT) تحت معدلات البذار الثلاثة.

أوضحت نتائج الدراسة أن طريقتي الزراعة (ZT 17+P) و (ZT 34+P) حقتتا أعلى قيم معنوية في

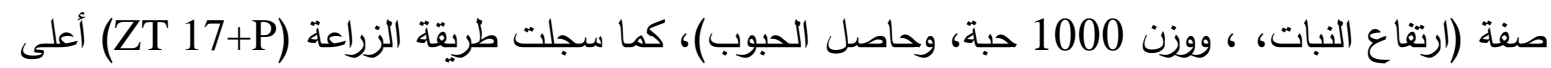

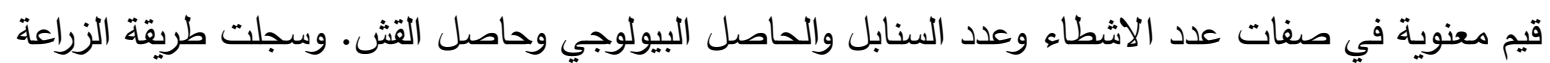
أعلى قيمة معنوية في صفة نسبة البروتين. وفي معدل البذار حقق المعدل (ZT 34+P) 1) أعلى فرق معنوي في صفات (عدد الاشطاء، وعدد السنابل، وحاصل الحبوب). في صفة حاصل الحبوب حقق التداخل بين طريقة الزراعة (ZT 17+P) مع جيع معدلات البذار وتداخل طريقة الزراعة (ZT 34+P) مع معدلي البذار (120و100كغم.هكتار -1) أعلى قيمة معنوية في حاصل الحبوب، في حين حقق التذاخل بين الزراعة التقليدية مع معدل البذار 80كغم. هكتار -1 أقل قيمة معنوية في حاصل الحبوب. الكلمات الدالة: الزراعة الحافظة، حاصل الحبوب، الزراعة الديمية.

\section{REFERENCES}

Alrijabo A. A.; A. A. Saad and A. A. Hisham (2014). Effect of zero tillage system, seeding rate and row spacing on growth, yield and its components of bread wheat in moderate rainfall area in ninevah province. Journal of Kirkuk University for Agricultural Sciences, (5). (1).

Alrijabo, A. A. and A. T. W. Mohammed Amin (2019). Response of tow entrance barley cultivar for row spacing and zero tillage in moderate rainfall area of telkif. International conference for sustainable agricultural Fayoum J.Agri.Res and Dev,33(1) 
Amare, A. and K. Mulatu (2017). Response of bread wheat (Triticum aestivum L.) varieties to different seeding rate for growth, yield and yield components in kombolcha district,north-eastern ethiopia. Journal of Biology, Agriculture and Healthcare, 7(23).

Amina, B.; K. I. Muhammad; A. Waheed; N. Ali; Z. Muhammad, A. Shiraz; N. Ghulam; Saadia, and A. Muhammad (2019). Effect of varied seeding densities on growth, yield and yield attributes of different wheat (Triticum aestivum L.) genotypes of Pothohar region. Int. J. Biosci,15(1):216- 224.

Avtar S., S. B. Karampal and G. Navdeep (2019). Effect of spacing and different sowing methods on yield of wheat (Triticum aestivum L.) crop. Journal of Pharmacognosy and Phytochemistry 2019; SP4: 42-44.

Bibek, T.; R.K. Babu and M. Santosh (2019). Effect of conservation agriculture on yield and yield attributing properties of wheat. Advances in Plants and Agriculture Research, Volume 9 Issue 2.

Chhokar R.S.; R.K. Sharma; S.C. Gill and R. Kumar (2017). Influence of tillage, cultivar, seed rate and planting geometry on wheat yield, J. Wheat Res; 9(1):12-20.

Dongqing, Y, Tie C. Yong, L. and Zhenlin W. (2019). Optimizing plant density and nitrogen application to manipulate tiller growth and increase grain yield and nitrogen-use efficiency in winter wheat., Peer j,7-26 February 2019.

Fakhir (2016). Growth and yield response of wheat (Triticum aestivum L.) to tillage and row spacing in maize-wheat cropping system in semi-arid region. Eurasian J Soil Sci, 5 (1): $53-61$.

Farooq M. and K. H.Siddique (2015) Conservation Agriculture: Concepts, Brief History, and Impacts on Agricultural Systems,.in Conservation Agriculture, Springer, Cham, Switzerland.

Ghafari, S R. D. ; A. Hamayoun ; Q M.H. Mohammad and AH.Omran, (2017). Effect of row spacing on different wheat (Triticum aestivum L.) varieties in semi-arid region of Kandahar. International Journal of Applied Research.3 (7): 93-97.

Ghaley, B. B.; T. Rusu; T. Sandén; H. Spiegel; C. Menta; G. Visioli and D. Vrebos (2018). Assessment of benefits of conservation agriculture on soil functions in arable production systems in Europe. Sustainability, 10(3), 794.

Giraldo, P.; E. Benavente; F. Manzano-Agugliaro and E. Gimenez (2019). Worldwide Research Trends on Wheat and Barley: A Bibliometric Comparative Analysis. Agronomy 2019, 9, 352.

Honsdorf, N.; N. Verhulst; J. Crossa; M. Vargas; B. Govaerts and K. Ammar (2020). Durum wheat selection under zero tillage increases early vigor and is neutral to yield. Field Crops Research, 248, 107675

Kassam, A.T. Friedrich and R. Derpsch (2019). "Global spread of conservation agriculture," International Journal of Environmental Studies, vol. 76, no. 1, pp. 29-51.

Latif, A., Ahmad, M. I., Asghar, W., Ahmad, J., Abbas, A., Ahmad, M. Z \& ,. Mubarak, M. U. (2018). Evaluation of wheat performance under different 
sowing techniques in agro climatic conditions of KPK, Pakistan Journal of Biodiversity and Environmental Sciences (JBES), 12(3):349-354.

Mamta and Sh. Roopkishore (2019). Competitive ability of phalaris minor and wheat(Triticum aestivum L.) at variable density. Journal of Pharmacognosy and Phytochemistry.1:121-123.

.Omara, P., Aula, L., Eickhoff, E. M., Dhillon, J. S., Lynch, T., Wehmeyer, G. B. and Raun, W. (2019). Influence of No-Tillage on Soil Organic Carbon, Total Soil Nitrogen, and Winter Wheat (Triticum aestivum L.) Grain Yield .International Journal of Agronomy Article ID 9632969, pages(1-9).

Santín-Montanyá,M.;Fernández-Getino,A.;Zambrana,E.;Tenorio, J.(2017). Effects of tillage on winter wheat production in Mediterranean dryland fields. Arid Land Res. Manag. 2017, 31, 269-282.

Shafaqat A. ; I. I. Z. Muhammad; F. Mujahid; F.A. Muhammad; R. Muhammad; A. Rehan and $\mathrm{H}$.

Sharma S.; Tomar S.S.; N. Joshi; A. Sharma; A.K. Sharma and A. Galav (2018). Effect of various row spacing on wheat (Triticum aestivum L.) varieties in black cotton soil in south east Rajasthan. Int. J. Adv. Sci. Res. Management.; $\operatorname{Vol}(1): 155-157$.

Singh, B.; M. Kumar and A. K. Dhaka (2017). Improvement of wheat (Triticum aestivum L.) yield by different row spacing and varieties. Journal of Wheat Research 9(1): 21-26.

Tarolli, P.; M. Cavalli and R. Masin (2019). High-resolution morphologic characterization of conservation agriculture. Catena, (172): 846-856.

Woźniak, A. (2020). Effect of cereal monoculture and tillage systems on grain yield and weed infestation of winter durum wheat.International Journal of Plant Production: (1) 14 pp: 1-8.

Appendix (1) Analysis of Indepented comprisions of wheat traits in Glyukhan site

\begin{tabular}{|c|c|c|c|c|c|c|c|c|c|}
\hline $\begin{array}{r}\text { Sources of } \\
\text { variation }\end{array}$ & df. & \multicolumn{2}{|c|}{ Plant height $\mathrm{cm}}$. & \multicolumn{2}{|c|}{ Tillers No. $\mathrm{m}^{-2}$} & \multicolumn{2}{|c|}{ Spikes No. $\mathrm{m}^{-2}$} & \multicolumn{2}{|c|}{$\begin{array}{l}\text { No. Grains per } \\
\text { Spike }\end{array}$} \\
\hline $17 \mathrm{~cm}$ vs $34 \mathrm{~cm}$ & 1 & 8.18 & & $* * 66815.3$ & & $* * 60221$ & .16 & 11.87 & \\
\hline$(+\mathrm{P})$ vs $(-\mathrm{P})$ & 1 & $* * 721.46$ & & $* * 76199.9$ & & $* * 10732$ & 6.13 & $* * 85$ & \\
\hline ZT vs CT & 1 & $* * 292.66$ & & 112.21 & & $* * 17408$ & 1.63 & $* * 54$ & \\
\hline $\begin{array}{c}\text { Sources of } \\
\text { variation }\end{array}$ & df. & $\begin{array}{l}\text { 1000grain } \\
\text { weight } \\
\text { gm. }\end{array}$ & & $\begin{array}{l}\text { ological } \\
\text { yield } \\
m^{-2}\end{array}$ & & ield & $\begin{array}{l}\text { Stra } \\
\text { gm }\end{array}$ & ld & $\begin{array}{l}\text { Protein } \\
\%\end{array}$ \\
\hline $17 \mathrm{~cm}$ vs $34 \mathrm{~cm}$ & 1 & 0.97 & & 816945.43 & $* 3$ & 84.93 & $* * 51$ & 01.09 & 0.03 \\
\hline$(+\mathrm{P})$ vs $(-\mathrm{P})$ & 1 & $* 13.08$ & & 670073.76 & $* * 4$ & 8918.18 & $* * 1$ & .91 & $* * 2.67$ \\
\hline ZT vs CT & 1 & $* * 25.16$ & & 946540.04 & & 0516.67 & $* * 20$ & 52.67 & $* * 1.76$ \\
\hline
\end{tabular}

